American geologists as of great promise in this respect. Three discoveries have been reported in this State recently, according to Science Service of Washington, D.C. In two instances, students of the University of Nebraska have discovered flint implements in association with the bones of fossil bison under some sixteen feet of loess which, it is claimed, is earlier than the last glaciation. These two discoveries lie about sixty miles apart. The third discovery was near the town of Angus, where, it is claimed, a flint implement was found under the scapula of a mammoth. The sites have been visited by Dr. W. D. Strong, of the Bureau of American Ethnology, who regards the discoveries with very considerable reserve.

\section{Antiquities from the Ancient East}

ON July 11 two exhibitions of antiquities found in the course of excavations during the past season were opened in London, at University College, Gower Street, and at the British Museum. At University College, Sir Flinders Petrie has on exhibition the finds of the expedition of the British School of Archæology in Egypt at Tell el-Ajjul, the ancient Gaza. The antiquities from the Hyksos levels will give an added attraction to the exhibition in the estimation of the general public ; but the real interest of the collection as a whole lies rather in its extent and completeness in range over Palestinian cultures from the copper age to the time of the eighteenth dynasty and later. A quantity of pottery from the Agæan and Mycenæan civilisations, from Egypt, Cyprus, and elsewhere, indicates the importance of the site as an early meeting point of international lines of communication. Particularly to be noted among the exhibits are fine daggers of the copper age, alabaster vases of the eighteenth dynasty, and glass of the same period. Two finds to which attention has been directed in preliminary reports on the season's work-the group of battered vessels and gold and silver, associated with burnt bones, which seem to be of the nature of a comminatory offering, and the gold ornament of tore form for which Irish affinities have been suggested - will certainly attract notice. The exhibition will remain open for four weeks.

AT the British Museum the collection of antiquities yielded by the past season's excavations at Ur will remain on exhibition for a period of three months. The character of the work, although it was essential and might have proved of the greatest value scientifically, was not such as would be likely to afford spectacular results for exhibition purposes comparable with those of recent years. There is, however, a number of gold frontlets and beads and a striking terra-cotta figure of a god with a mitre of bull's horns in the best tradition of Ur. There are also a limestone statuette of the goddess Pa-Sag and a copper statuette of the same deity, the latter discovered in the pedestal of a limestone figure. These belong to the third dynasty. A steatite bowl of the same period shows the figures of five oxen as decoration. One of the most interesting items in the collection is the steatite stamp soal assigned to Mohenjo-daro as its place of origin, on which are engraved an Indian buffalo and an inscription in the script of the Indus valley. Mention must also be made of the collection of types of beads from about 4000 B.c. down to the Persian era of the fourth century B.C., and the collection of seal-impressions from various sources which, it is inferred, were once the property of a jewel collector at Ur.

\section{The Freshwater Biological Association}

THE annual general meeting of the Freshwater Biological Association of the British Empire was held on June 29, and Mr. Reginald Beddington was elected president. The Report for the year shows that the Association, which was established as the outcome of a discussion at the meeting of the British Association at Glasgow in 1928, has made considerable progress during the past year. Support has been received from the Development Commissioners, scientific societies, waterworks associations, fishery boards and angling associations, and many private individuals. 'The interests of anglers are vory closely concerned with research into the conditions existing in fresh waters, but not as much help as was expected has been received from those directly interested in angling. In September the Association opened a laboratory on the shore of Lake Windermere, certain rooms in Wray Castle, a property owned by the National Trust, having been equipped for this purpose. There are two naturalists employed in research at the labora. tory, and there is accommodation for visiting research workers. A number of workers from Great Britain and from abroad have already occupied tables in the laboratory. There is a launch for work on the lake, and this launch is fully equipped for hydro-biological research. In extending its programme of research the Council of the Association has felt the difficulty of a lack of funds. A special appeal is made to all who are interested in fresh waters to support the Association. The address of the honorary secretary is Mr. J. T. Saunders, Christ's Collego, Cambridge.

\section{Photographic Copying by Contact}

Is the early days of photography, the late Mr. J. H. Player invented a method of making full-sized copies of black and white print, drawings, etc., without the use of a camera or lens. The process, known as 'playertype', is easily worked and may sometimes be used with advantage. The drawing to be copied is taken to the dark room. A sheet of ordinary bromide paper, or a photographic plate, is placed with its sensitive surface in close contact with the drawing. The paper is then exposed for a short time to the light from any convenient ordinary source of white light of low power. The light passes through the paper and its sensitive coating, illuminating the drawing beneath. Less light is reflected back from the black lines of the drawing than from the white ground. Thus the total illumination of the sensitive coating opposite the black lines is less than that opposite the white ground. On developing the sensitive material a somewhat foggy negative is obtained. This negative can be used for

No. 3272 , VoL. 130] 